\title{
On the Imperative of Language for Un- derstanding African Art
}

\author{
Rowland Abiodun \\ Amherst College \\ roabiodun@amherst.edu
}

I was deeply touched and honored by the roundtable organized at the 2016 African Studies Association Conference to focus on my book, Yoruba Art and Language: Seeking the African in African Art (2014). I want to thank Professor Funșọ Afọlayan for contacting and bringing together a formidable group of scholars of Yorubá art and culture to that end.

I was gratified that, by and large, all the panelists endorsed my premise on the fundamental importance of language in Yoru bá art studies. The first paper by Moyọ Okediji was a pleasant surprise. Even though this possibility has always existed, as I had taught a course in Yoru bá art entirely in Yorubá language at the University of Ifẹ (renamed Ọbá fẹ́mi Awólọ́wọ University) in the $1980 \mathrm{~s}^{1}$, no one was expecting that his entire contribution to the roundtable discussion would be presented in Yoru bá language. Why not? I realized. The language is as fully developed as any other language in the world and it can, and should be spoken as well as written -- especially when we discuss Yorubá art. For the benefit of those not literate in Yoru bá language, Michael Afọlayan gave an elegant translation of Okediji's paper in English. The excellent contents and presentation by Okediji touched on issues that lay at the heart of my book, namely its methodology and its insistence on the need for a Yoruba' voice to be heard literally and metaphorically in art historical discourse.

I will devote more space to Kathy Curnow's paper because of its deeply problematic nature which raises fundamental questions and debates about the present and future of our field. Curnow, writes that "He [Abiodun] notes

1 This experience was most rewarding for me and the students. They were not only active critics of terms and ideas generated by scholars not literate in Yoruba language but also most insightful contributors to the discovery and formulation of new and more appropriate terms to characterize Yoruba art forms and analyze them, aided by their training in the department of African languages and literatures.. 
some Western art historians refer to African art as 'primitive', 'rarely venture outside of Western paradigms, even when they analyze works from non-Western cultures' and judge Yoruba sculpture by Western standards. Fifty years ago this was true, but the scholarly world has changed considerably." (Italics mine). Let me re-state my argument from my book, Yoruba Art and Language:

It is useful to give very brief but necessary background information about African art studies (with which many but not all of my readers may be familiar) to understand their link to the methodological problems still facing the discipline today. To support this move, I offer the following Yoru bá òwe, generally translated as a proverb. "Wọ́n ní, Amúnkún, ẹru ẹ wọọ. O' ní, 'İsàlẹ ló ti wọ wá." ("People said, Cripple, your load is crooked. He responded that, the crookedness was from the ground up.") (In considering a problem, one must look at the root causes, not only its manifestations.) Most art scholars will acknowledge that because of the aesthetic, cultural, historical, and political predispositions built into the development of art history, the discipline itself has resisted non-Western approaches to the study of African art. (pp. 8-9).

It is laudable as Curnow reports, that "African art historians have long blasted the 'primitive' moniker and also distanced themselves from past formalistic-only approaches". This step, though important, is not enough reason to exclude the study of terms like "primitive art", "ethnographica curiosa" and many more when we critically examine the history and narrative of methodological problems in African art studies. In other words, we are not yet totally out of the woods methodologically, and the field is still evolving.

If indeed, "the scholarly world has changed considerably" as Curnow claims, where is the evidence for African-derived paradigms in the study of African art? As I stated on page 11 of my book, "Clearly, any decision to ignore Africa's unique perspectives and languages on art and creativity as a whole would only hasten the loss of her well-deserved place in the international art scene."

Roy Sieber, a pioneer and leader in the field of African art studies in the United States who also happened to be Curnow's professor, rightly observed that:

Art is a cultural manifestation finally to be understood (as distinguished from "appreciated") only in the light of its cultural origins... . Admiration in isolation easily leads to misunderstanding, and African art, its functions vaguely apprehended, has fallen prey to the taste of the twentieth century. ${ }^{2}$

2 Roy Sieber, 1971: 127. 
Beyond that, he pointed out:

Like most art in the history of the world, African art is deeply involved in the sensible and spiritual goals of human beings. Instancing and symbolizing security, it lies at the center of a hard core of beliefs." 3

This insightful comment by Sieber challenges all Africanist scholars (including Africans born and raised in Africa) to begin to take seriously the issue of understanding as distinct from merely appreciating African art and indeed Yoruba art, the focus of my book. Sieber was calling for the same measure of intellectual rigor and professional thoroughness often demanded in Western art history to be applied to the study of African art. He did not warn against the acquisition of relevant African languages to achieve this goal. Rather, he warned against "admiration in isolation" and falling "prey to the taste of the twentieth century". I argue that it is impossible to understand African art in the light of "its cultural origins" without a command of the relevant African language.

It is taken for granted that the most respected and finest scholars of Western art history are fluent or nearly fluent in the reading, writing and speaking of the languages of the people whose art they study. Even scholars, whose mother-tongue is, for example, English or another European language, are not exempted from this demand for their research to be credible. It would therefore be a mistake - a misrepresentation - to suggest that I am arguing that you have to be Yorubá by birth to understand Yoru bá art. That would be as absurd as saying that you have to have been born in Italy to understand Michelangelo. I argue that it is fundamentally important for a scholar of African art - whether they are born in Ilé-Ifẹ or Los Angeles - to learn the relevant African language and immerse themselves in it.

As professionals in the study of African art, why should the bar be lower? Our goal should not be only to "appreciate" African art but also to "understand" it. We would like to know how scholars of Chinese, Indian, or even Western art history who learn the languages of the cultures they study would respond to Curnow's statement that "working with the art of bygone centuries makes all scholars outsiders." (Italics mine).

Curnow has set up a dichotomy that I find deeply problematic even though it is obvious that this is what she would wish for the field of African art studies. Besides, it is faulty logic. I do not believe and have never said that some scholars are irreparably locked out of African art studies and others are not. What I am calling for is a remedy for what is lost when scholars do not make enough effort to study African art from an African perspective. I maintain that there is a drastic difference in the possibilities of understanding between scholars who have invested time, energy, and resources to learn and have a

$3---1971: 128$. 
command of the languages and deep knowledge of the cultures they study and those who do not.

It is helpful to find out what Yoruba thought has to offer regarding the study of its art. Take for example, iwà (the Yorubá term for the essential nature of a thing, object or person). ${ }^{4}$ Not to understand or to undervalue this important prerequisite for ewa (the full and proper appreciation of a person or thing in itself) and to favor instead external criteria or explanations will not only further remove us from the Yorùbá aesthetic universe but also rob us of the full appreciation and understanding of Yorùbá art.

Fortunately, scholars of Yorùbá ancestral thought and literatures, with their wealth of oral data, can be of immense help to Yoruba art historians whose studies need to be less speculative and more oriented toward Yorùbá thought.

Related to $i w a$ is another important aesthetic concept called ojú-inú (literally translated as "inner eye"). Ojú-inú refers to insight, a special kind of understanding of a person, thing, or situation. It underscores the intended message in the Yoru bá saying, Imú ni àlejò fi i ríran, "The stranger ('one with untrained eyes') usually sees only through the nose." "Without ojú-inu', one with untrained eyes, like a child in ignorance, may call a medicinal plant an edible vegetable," ọmodé ò moògùn ó n' pè é ní ẹfọ́.

To be clear, ojú-inú is the intellect with which one perceives the individualized form, color, substance, outline, rhythm, and harmony of the subject. Such perception can be acquired through indigenous and culturally-situated sources such as chants, songs, and oriki (citation and attributive poetry that may praise or be critical of its subject), by reference to Ifá and other divination literature (the intellectual powerhouse of the Yoru bá people), and, of course, extant examples of works of art. This sensibility is extremely important if the artists as well as the critic are to capture accurately the essential identity, character and function of their subject.

Curnow agrees that "Language mastery certainly provides the native speaker with access to inestimable insights regarding not only general worldview, but specifics of philosophy, history keeping and subtleties of knowledge transmission." (Italics mine). But then she adds that,

However, in the attempt to read an artwork and unpack its meaning, cultural insiders also face obstacles as well as advantages. Problems can magnify when the works date from the more distant past. The import of Abiodun's major contributions regarding Yoruba's art history and the validity of his contentions are considered in light of the varied contributions both foreign and Yoruba art historians bring to Yoruba scholarship, in the recognition that working with art of bygone centuries makes all scholars outsiders. (Italics mine).

4 See Abiodun $(1983,1984)$ 
Further on, Curnow asks pointedly, "Do insider advantages always trump outsiders' perceptions?" By asking this question, it appears that she was setting the stage to express her reservations or perhaps, even signal the withdrawal of her endorsement for "language mastery" which she gave earlier. So, it does not come as a surprise when she plays down or blunts the impact of my contribution when she writes that, "Abiodun's deep linguistic and cultural knowledge facilitate his art historical interpretations of Ife works, yet these abilities cannot guarantee accuracy... Likewise Abiodun's claim that, since representing the Oọni would have been unthinkable as recently as the 19th century, it is arguable that Ife bronzes could not have depicted the monarch." (Italics mine). In pushing the argument about whether or not Ifẹ bronzes could have depicted the monarch, it is telling that Curnow omitted how and why I came to my conclusion on the ancient works of Ifẹ

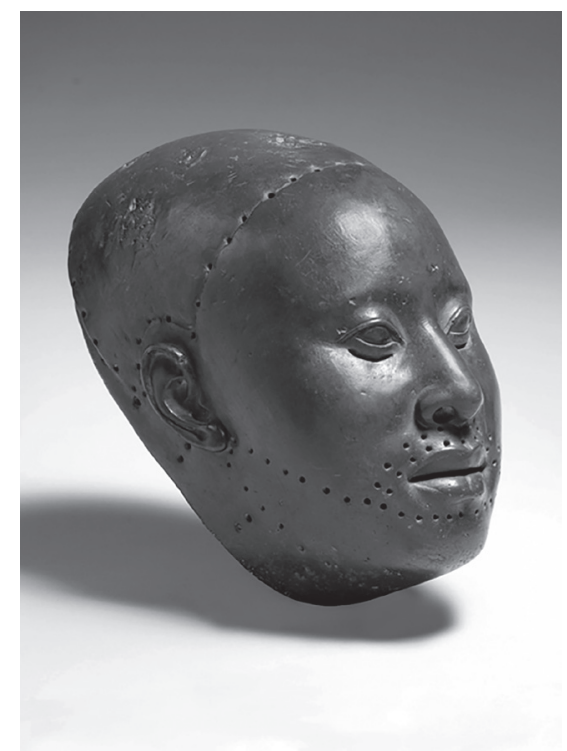

Figure 1: Mask called "Obalùfọn," Ife, Nigeria; Fourteenth-fifteenth century C. E. Copper. Height: 13ins $(33 \mathrm{~cm})$. Reproduced by permission of the National Commission for Museums and Monuments, Nigeria, 38.1.2 and courtesy of the Museum for African Art, New York, USA

It was not easy, as I stated on page 212 of my book:

For most Western-trained art scholars - even for me, Yorubá-born and native-speaking - it has, no doubt, been extremely tempting to link Ifẹ naturalism with Ifẹ kings and rulers. Not only is such a hypothesis quite 
appealing to Yoruba indigenes but also to the researcher who is more inclined to rank Ifẹ naturalism as a superior style (or àsà) fit only for Yoru bá kings. It is not always easy to see that these suppositions belong solidly with the same Frobenius argument that Greco-Roman classical traditions in Western art represent a more "advanced" civilization - a proposition that continues to inform the theses of virtually all Western-educated scholars on the origins of Ifẹ naturalism. Mesmerized by the pronouncements of the most prominent art scholars in the field, researchers have been most reluctant to explore afresh what Ifẹ naturalism could mean to the society that is responsible for the magnificent works from ancient Ilé-Ifẹ̀.

Scholars of African art are still tempted to rely on Western notions of "naturalism" to solve what has been, and still is perceived by many as an anomaly in the history of African art. Thus, calling just about every Ifẹ head "classical" or labeling them "kings or queens and removing them from the category of "primitive art" may seem harmless, perhaps even flattering. This has made it extremely difficult to pursue the search for the real meaning(s) of Ifẹ naturalism. Many scholars, though well-meaning, have never bothered to ask the hard questions about Ifẹ art.

Now, let us return to Curnow's assertion that "working with art of bygone centuries makes all scholars outsiders." So she is saying that in these cases, the knowledge obtained from indigenous language and culture cannot be of any use. The implication is that Leo Frobenius' 1913 conclusions on the ancient art from Ilé-Ifẹ, for example, must have the same validity as mine. I will not dispute the fact that Frobenius was an imaginative scholar, but he was certainly far from being knowledgeable in the culture and language of Yorubá people. Thus, he was not qualified to speak for the Yoruba people and their art in his book which he, ironically, titled "Voice of Africa." Frobenius in his own words writes of the art of ancient Ifẹ::

Here were the remains of a very ancient and fine type of art ... these meager relics were eloquent of symmetry, vitality, a delicacy of form directly reminiscent of ancient Greece and proof that, once upon a time, a race far superior to the negro has been settled here. ${ }^{5}$

In her efforts to help scholars like Frobenius gain credibility without the acquisition of the relevant language skills and cultural knowledge of the people whose art they study, Curnow presents a dichotomy that would make it possible for all scholars to be equals. Yet, this strategy does not appear to

5 Frobenius, 1913: 88-89. 
resolve the problem as she would have wished. In the following praise for the work of Abiodun who according to her categorization is an "insider", we see how she struggles with this dilemma:

"His [Abiodun's] overarching contribution, however, may be the invention of three terms that are truly illuminating categorizations. They grow from deep linguistic and cultural reflection, and have the ability to change the perspectives of those who employ them.... While his terminology can be applied to traditional Yoruba art of any era, it is particularly helpful when applied to the more distant past, such as those terra cottas and bronzes from 11th - 15th century Ile-Ife or early ivories or terra cottas from Owo."

My work is on-going and I'll be the first to admit that it can be improved through constructive criticisms from colleagues in and outside our field. It is in this spirit that I heartily welcome Curnow's question as to why, for example, the Seated Tada figure's dress "(which Abiodun considers to be shorts, but might well be a wrapper tucked through the legs and in at the waist) decidedly informal?" My decision to call what the Seated Tada figure is wearing is based on visually compelling evidence from several sources - all of which I have carefully documented in my book. I will re-state them.

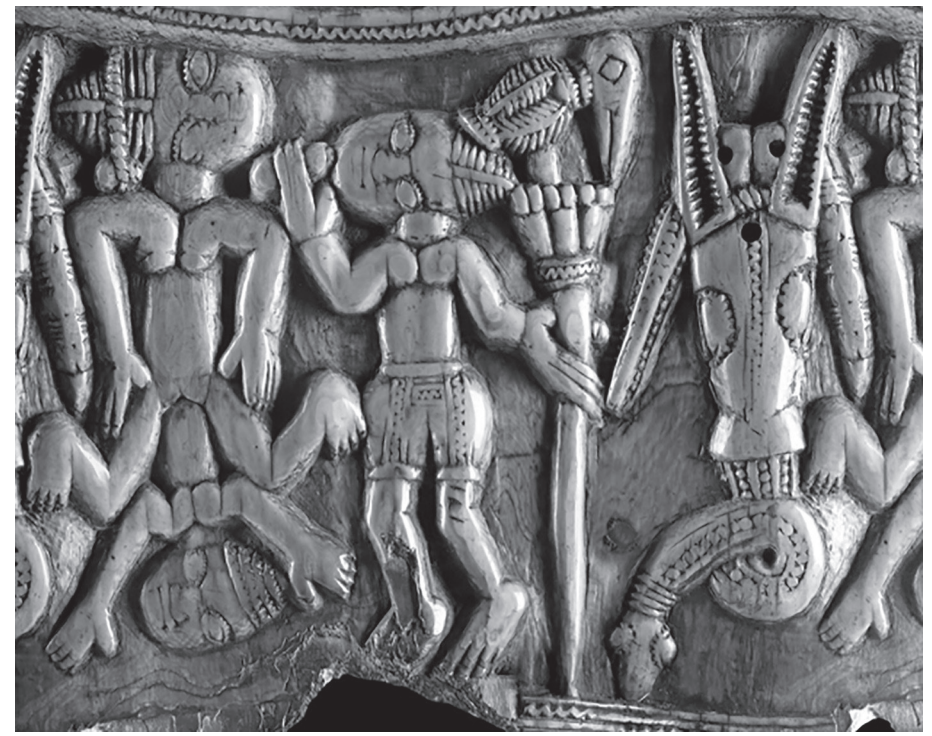

Figure 2: Panoramic view of bottom section of iróké, Ifá divination tapper, Owo, Nigeria. Fifteenth - sixteenth century C.E. Ivory, Height: $44.5 \mathrm{~cm}$. Reproduced by permission of Rolf Miehler. 


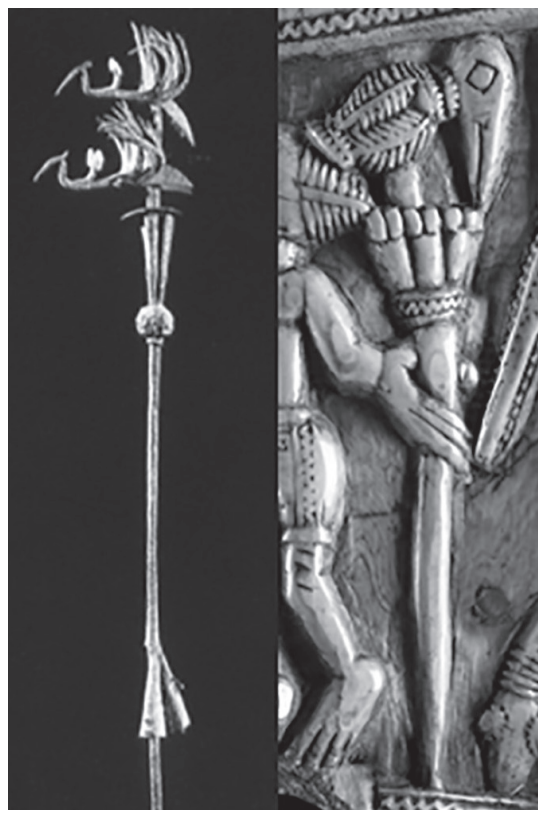

Figures $3 a$ and 3b: Osùn babaláwo, (Ifá priest's staff of àșe juxtaposed with close-up of similar staff on iróké babaláwo in ivory. The iron Osùn is 39 3/4 inches in height and dates to mid-20th century, reproduced by permission of Drs. John and Nicole Dintenfass and courtesy of the Museum for African Art, New York, USA; the irókẹ babaláwo (Ifá divination tapper in ivory, Owo, Nigeria, dates to 15th/16th century and measures $44.5 \mathrm{~cm}$, reproduced by permission of and courtesy of Rolf Miehler, Germany.
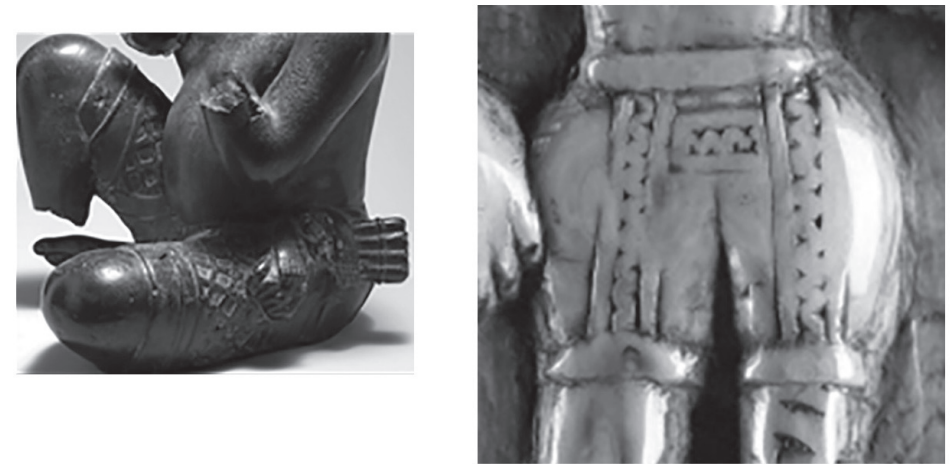

Figure $4 a$ and 4b: Close-up views of Tada Seated Figure's short pants; and similar pants worn by an Ifa priest on divination tapper in ivory, reproduced by permission and courtesy of Rolf Miehler,

Germany. 
The first example comes from a $16^{\text {th }}$ century (írókẹ) Ifá divination tapper in ivory (figure 110) in my book.

A panoramic view of the bottom section of an ivory iróké from Ọ̀wọ, dated sixteenth century ... lends support to the notion that this simple but sophisticated dress code for celebrated Ifa priests must be a few hundred years old. ..The figure in the center is identifiably a leading Ifá priest, based on the scepter osun babaláwo ... that he holds in his left hand and the àdo' (a medicinal gourd) on the right. Osün babaláwo (also known as ọpá ọrẹrệl òpá os sooro) is a scepter or staff usually surmounted by a bird motif called Eyẹkan or eye oko (the lone and wild hermaphroditic bird) but which was later renamed Eyẹ'lé (the pigeon or the domesticated bird) when it was able to reproduce and became two. Thus, Eyẹkàn became the symbol of the Ifá priest's àse to heal, and confer blessings of ire owó (riches), ire omo (chil-

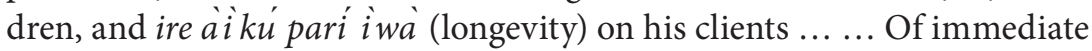
interest to us in this scene, however, is the pair of short pants worn by the babaláwo - its construction, design, and similarity to the short pants worn by the seated bronze figure from Tada. Though gathered at the waist to create a certain billowing effect, these short pants are quite close in design to the pair worn by the Tada seated figure. Both pairs of short pants are not long enough to reach the knees and have bands at the waist and, are at the bottom of each pant leg. The zig-zag designs on the fabric of the short pants on the standing figure in ivory appear to be embroidered or at least raised. The diamond designs on the Tada figure are related aesthetically to the zigzag designs on the iróké because both are variations of the same basic design. Though in different media, copper and ivory, - these designs show a preference for an embroidered or slightly raised fabric. Equally noteworthy is that in both media, the torsos of the figures are bare-chested which coincides with the images of Ifá priests in Chapter 4, Figure 59, and chapter 5, Figures 74 and 75 of my book. In all, there is convincing evidence that the Seated Figure from Tada is a distinguished Yorùbá diviner in Nupe country.(See pages 234, 235 of my book).

The Seated Figure from Tada is decidedly professional in pose and dress of his time. More importantly, this exercise demonstrates convincingly how a good knowledge of the language and culture can yield a meaningful interpretation when "working with the art of bygone centuries".

Curnow also raises another important question,

"If ako figures have never represented royals in Abiodun's hometown of Owo in living memory, must we assume that this could never have 
happened six hundred years ago in Ife? Counter to Abiodun's assertions, similar figures (with the same name) that represent both the Oba and his mother ... do make funerary appearances in the cognate culture of the Benin Kingdom."

A quick and easy answer if I had not done any intensive research on the subject of ákó in Ọwọ would be yes for the same reasons that Curnow has already given. But my answer is no and I will re-state my argument as succinctly as possible.

In Yoruba culture, there is a fairly wide range of preexisting àșà (style, tradition, custom - all of which are, by definition, always time framed) from which the artist may choose. If the carving was for an àkó second-burial effigy in Ộọ̀, the artist worked in total seclusion for several months or more, and conformed to an àkó-graphic așà (an artistic style, tradition, custom which preceded photography probably by more than 500 years).

This effigy aims for a high degree of resemblance to the deceased. During the outing or public presentation of the ákó effigy, what the audience experienced was an exceptionally well-executed sculpture which most people

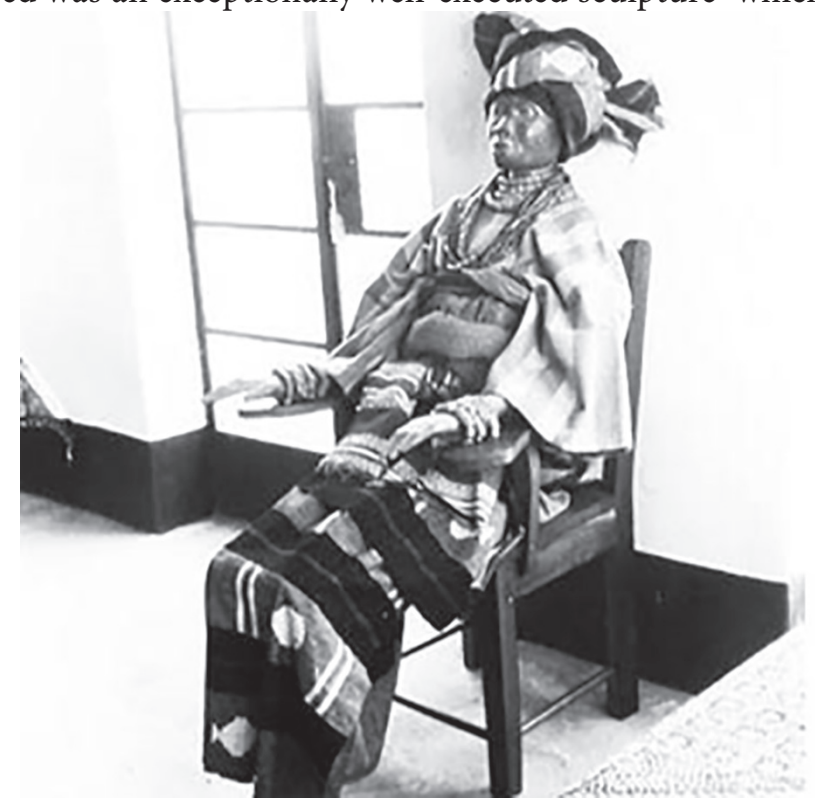

Figure 5a: A`kó figure of Ameri Ọláșubùde, (mother of Olátẹru Olágbègí II, Olọwọ of Ọwọ). Artist: Ògúnléye Olọgán. Photo by William B. Fagg, 1959; Object number PSC1986. 3. 779. Image number: PCB 4823. Courtesy of the Royal Anthropological Institute of Great Britain and the Metropolitan Museum of Art, New York, USA 


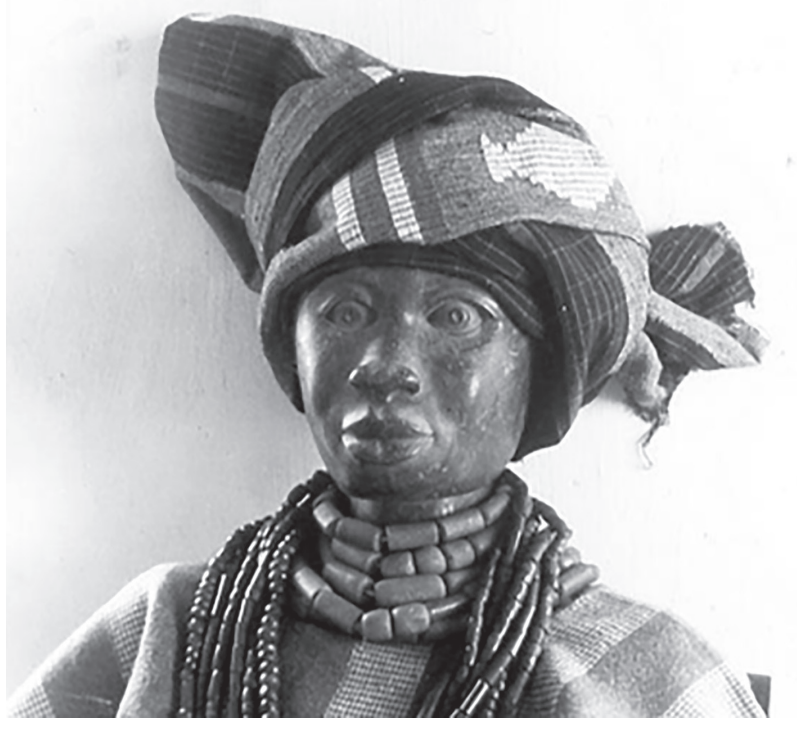

Figure 5b: Close-up view of the A'kó figure for Ameri Oláșubude (mother of Olátẹrù Olágbègí II, Olọwọ of Ộoọ). Artist: Ògúnléye Olọgán, Photo by William B. Fagg, 1959. Object number: PSC 1986. 3. 1774. Image number: PCB 4818. Courtesy of the Royal Anthropological Institute of Great Britain and the Metropolitan Museum of Art, New York, USA

believed was not made only by human hands. The artist, the audience thought, must have been assisted by some otherworldly beings or or is àa.

Yet, there continues to be much confusion about àkó in Ọ̀ wọ and Benin ${ }^{6}$ on the role of akkó effigies in Òwọ, Frank Willett has used R. E. Bradbury's conclusion on the role of "similar" effigies also called a ko in Benin. For them, the effigy is to "symbolize the continuing nature of the chiefly office despite the death of the temporary holder." Assuming that this idea is true of Benin ako, Willett did not offer us sufficient reasons for thinking that the same must be true of Oọ à $a^{\prime} k o$, either in the past or present, apart from the fact that both effigies are known by the same name. Furthermore, Willett's unifunctional assumptions in his àkó study must have prevented him from recognizing other possibilities. In any case, the Benin a ko' effigy from which Willett suggests the O'wọ form must have been derived is "a figure of red cloth sewn over a piece of wood for a nose and clothed in chiefly beads." (Italics mine). The least

6 I have addressed this problem more broadly in Abiodun (1997).

7 Frank Willett, 1966:34

8 ----, 1966: 35; also Plate 42. 
we can do to counter this hypothesis is to visually recognize the clear difference between Benin and Oọ a kó effigies.

Most importantly, a ko in Ọwọ is known and fully identified in Òwọ́nrín

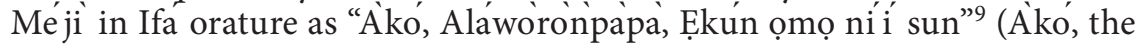
Restless, Who mourned his lack of children). A focused and intensive study on the meaning and function of àkó in Benin similar to the one I have done on $a^{\prime} k o ́$ in Owo is long overdue. Until this has been done, any pronouncement

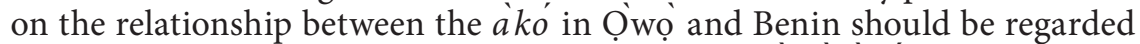
as purely speculative. A more detailed account of O'wọ a kó is contained in my work, "A Reconsideration of the Function of A'ko', Second Burial Effigy in Öwo", AFRICA 46, (1) 1976: 4-20, and Chapter 6 of my 2014 book. I also have a chapter, "Ọwọ et le Mythe de la Benin-isation," in Arts du Nigeria, edited by Jean-Hubert Martin, Etienne Féau and Hélène Joubert, 1997:55-58: Paris: Le Musée: Reunion des musées nationaux, that addresses more broadly the Ờộ-Benin relationship.

On the subject of Orí, Curnow states that my chapter on Orí-inú was "far from the first" ${ }^{10}$ This assertion is incorrect.

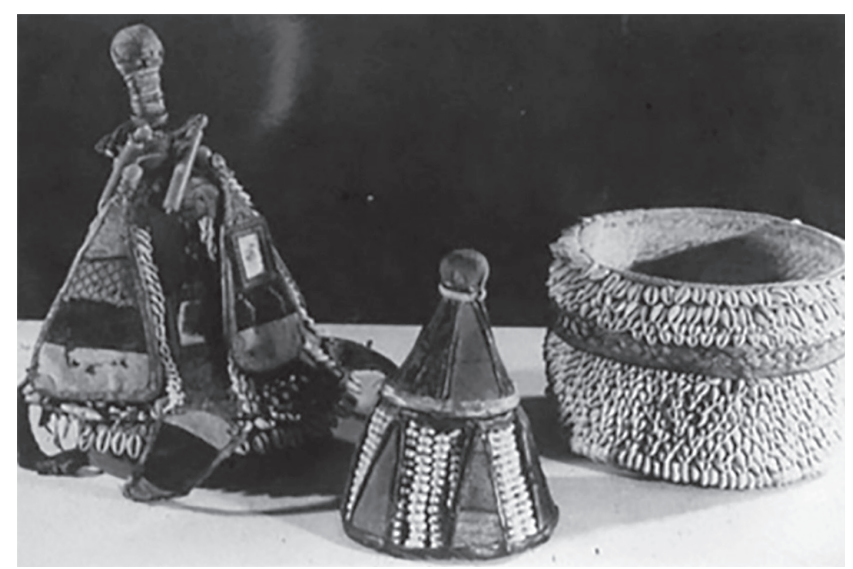

Figure 6a: İborí, representing Orí-inú (center) is displayed between the top and the base of the Ilé-Orí ('house' of Orí-inú). Hide, cloth, and cowrie shells.

Height: $10 \mathrm{~cm}$. Courtesies of Professor and Mrs Wande Abimbola (for the

İbori); and Professor and Mrs Richard Taylor (for the Ile-Ori). Photo: R. Abiodun, 1986. Ori-inú is the inner spiritual head and determiner of one's lot on earth.

9 Wande Abimbola, 1968: 76

10 On the subject of "firsts", I must correct another of Curnow's claims. The chronological list of Yoruba art historians is in error. I became a member of the faculty in Art and Art History in the Institute of African Studies at the University of Ife (now Obafemi Awolowo University) in 1970 when late Cornelius Adepegba was still an undergraduate at Ahmadu Bello University, Zaria. 


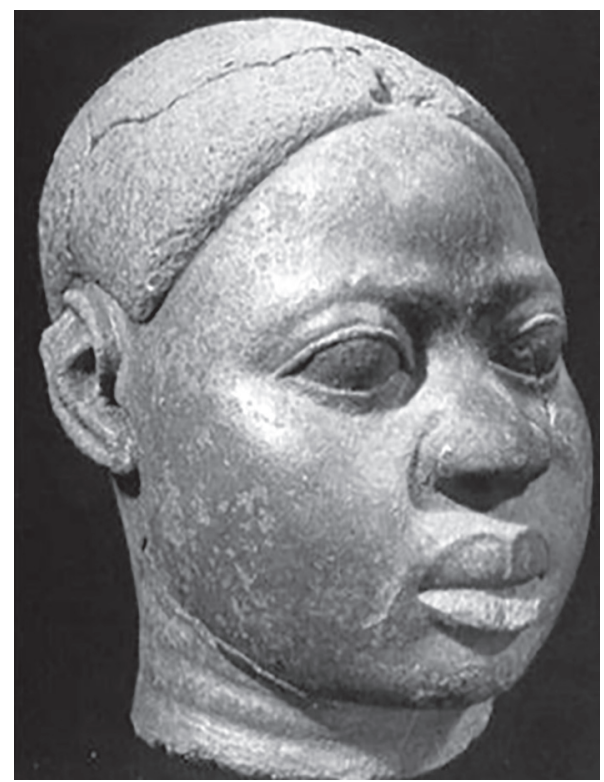

Figure 6b: Terracotta head from İta Yemòó, Ifẹ. Height: 7 5/8ins; Escav. No I. Y. 30/3. Courtesy of Frank Willett; Reproduced by permission of the National Commission for Museums and Monuments, Nigeria. This is an example of

Orí-ode the outer, easily recognizable, 'naturalistic' head

In fact, my first publication on the subject of Ori' and its interpretation dates to 1975, in my chapter on "Ifa' Art Objects: An Interpretation Based on Oral Traditions" published in Yoruba Oral Traditions edited by Wande Abimbola, 1975, pages 421-469, and so predated her claim that the first one was published in 1976. This was followed by my "Orí Divinity: Its Worship, Symbolism and Artistic Manifestation" published in the Proceedings of the World Conference of Orișà Tradition, Department of African Languages and Literatures, University of Ifẹ, Ile-Ife, 1981: pages 484-515. And in 1987, I published "Verbal and Visual Metaphors: Mythical Allusions in Yoruba Ritualistic Art of Ori'" in Word and Image, 1987, 3, 3: 252-270. What now constitutes chapter 1 on Ori" in my 2014 book has been drawn from all of the above works and more recent research on the subject of Orí. My original contribution to the scholarly debate on Ori" is the discovery of a clear graphic distinction between Orí-inú (also called 'Àkàtà-gbiri-gbìrì-gbiri' and 'Kótópó-kelebe'), the inner spiritual head, determiner of one's lot, and Orí-òde (the outer 'naturalistic, recognizable physical head) - a distinction which dates back to the $12^{\text {th }}-15^{\text {th }}$ century as is evident from the terracotta head and ritual pot excavated from Ifẹ. (See chapters 1 and 2 of my book). 
Even though Curnow acknowledges my Yoruba-derived paradigms of 'a'ko'graphic àșa', 'àse-graphic àșà', and 'èpè-graphic àșa' as "truly illuminating", she omitted the other equally important indigenous Yoruba' artistic and aesthetic terms and paradigms such as 'ojú-inu', 'oju'-ona', 'iluti', 'imojú-mora', 'títọ' ' $i$ farabalẹ' (six in all). I was the first scholar to introduce them into Yorubá artistic discourse ${ }^{11}$.

Also left out of Curnow's paper is my important contribution to a previously hitherto less researched aspect of Yorubá art - àsẹ,- a subject which now constitutes Chapter 2 titled "Ạsẹ: The Empowered Word Must Come to Pass" in my book.

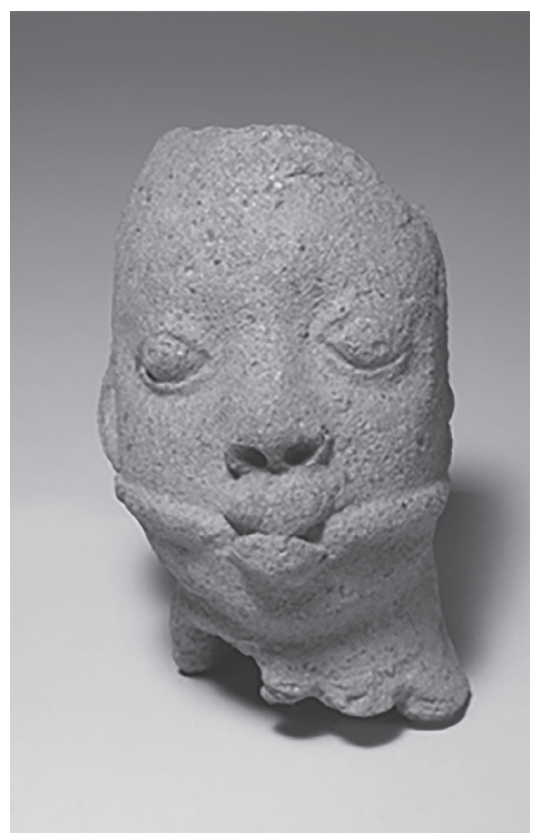

Figure 7: Gagged head. Òsángangan Obámákin, Ifẹ. Twelfth - fifteenth century c. e. Terracotta; Height: 5 1/4ins $(13.5 \mathrm{~cm})$. Reproduced by permission of the National Commission for Museums and Monuments, Nigeria, 49.1.20; and courtesy of the Museum for African Arts, New York, USA

To understand how așe works, we need to be familiar with the terms, jẹ (to answer), șe (to come to pass), and pè (to summon) - all of whose meanings illuminate the effectuation of power in àse and èpè (when așe is used to curse or harm). Consider the following Ifá divination verse:

Oòjọ tí a b'Èpè

11 See Abiodnn 1983, 1984, 1990, and 2014. 
Lapa'ṣe

Òojọ tí a b'óhùn

Lape’pè

Wọn pa'ṣe

Wơn pe'pè

Ohuin ló wà kù

The day Epè (Curse) was birthed

Was the day Àșe (Life-force) came into existence.

Likewise, Ohun (Speech) was born on the same day

Epè (Curse) was invoked.

Asse (Life-force) was asserted,

Èpè (Curse) was summoned,

But they both still need Ohuin (Speech) to activate them. ${ }^{12}$

Without Ohun ("speech," "voice," or "the performed word"), neither Ëpè (the malevolent component of life force), nor Așe, the largely beneficent component of life force - two sides of the same coin - can fulfill their mission. Thus, the main reason for gagging criminals before their execution, which is a theme in ancient Ifẹ art, most probably was to prevent them from inflicting èpe on their executioners.

But who or what is "Ohu'n"? "Ohưn” belongs to Ifá, È̀là, or Ộrúnmi là (often used interchangeably). Babaláwo (Ifá priests) assert that Ợúnmi là is the only orișa' that speaks and, therefore, the recognized "spokes-deity" for them. ${ }^{13}$ O'rúnmi là, the Yoruba' believe, is the only witness at creation; thus, he knows the original essence and name of every creature on earth including those of the orișa. And, because of Òrúnmi la's encyclopedic and authoritative knowledge, Ifa' (the divination system associated with Ộrúnmi la') has become indispensable to the activation of așe and èpè. Both $\dot{a}$ șe and èpè operate by identifying the targeted subject by their original or primordial name(s) and calling ( $p e)$ them. Thus, a targeted subject must answer or respond (jé or dáhuin) that is, obey the caller. Asse and Epè can be likened to "potent and effective traditional medicinal preparations which respond like the ignited fire" which is commonly known as $a$-jé-bí-ina..$^{14}$

12 Olabiyi Yai, Personal Communication, January 1994.

13 The Ifá literary corpus itself seems to be the source of this position. But more importantly, Ifá verses seem to be better preserved and therefore enjoyed greater use and circulation among Yoru bá diviners (including practitioners of Ėẹrindínlógún 'Sixteen Cowries' and Obi-dí da' Four-lobed kola nut). Be that as it may, all these systems speak, and are likely linked in ways that may not be clear to us.

14 This same term may also be rendered as "A-jẹ-bí-idán” (That-which-responds-likemagic), which conveys essentially the same meaning. 
'Jẹ' and 'dáhùn' have important aesthetic implications in Yorùbá art, especially under the aesthetic canon of ilutí. ${ }^{15}$ I lutí, literally "good hearing" determines whether or not a work of art "is alive" and "responds" that is, jẹ or dáhùn. In a nutshell, ílutí is a foremost criterion in determining if a work of art fulfills its artistic intention promptly and with precision. Black churches in the United States still say, "God is able!"16 This ilutí-like phenomenon is still very much alive in what has been generally labeled a "call and response" mode of worship. In West Africa, the Yorubá look for an orișà with ìlut $i$ to worship, as evident in the saying "Ẹbora tó luti la n' bọ", "We worship and celebrate only deities who can respond when called upon." ${ }^{\text {"17 }}$ Similarly, in judging art, $i_{\text {llut }}$ ' plays an important role. It aids a critic in determining whether or not the work in question is "alive," "responding," and "efficacious," that is jẹ or dáhùn. In essence, therefore, ì luti focuses on the fulfillment of artistic intention, as well as precision in the artistic process. ${ }^{18}$

For a work of art to have "the power to respond," the artist must have insight into his or her subject. Artists must possess the "inner eye" (ojú-inú) by which they can discern the "essential nature" (iwa) and use the citation poetry (oríki) of their artistic subject. ${ }^{19}$ With ojú-inú, an artist may identify and employ the right forms, colors, designs, and combination of motifs for, say, a Șàngó sculpture, Ọbàtálá altar, or Ọbalúwayé shrine as captured by Phyllis Galembo. or the costume for an ancestral masquerade, so as to imbue it with its proper identity and the așe of the specific òrișà. Without àșe, many an attractive work of art would fail to make an appreciable religio-aesthetic impact on their audience.

The warm reception and approval given a work of art by the community is considered quite important. For example, it is common knowledge that following an unenthusiastic reception of their work, amateurs and untalented carvers have quietly withdrawn to their farms or returned to petty trading, never to carve again. Though members of the audience are not always willing to discuss their reaction openly, a perceptive researcher can usually sense

15 For a fuller discussion of $i$ lutí, see Rowland Abiọdún, 1990: 78-79.

16 I am grateful to Professor Mei-Mei Sanford for calling my attention to this phenomenon in African American churches.

17 This statement is quite typical of Òrìsà devotees and celebrants at Ọdún-Ère (Festival of Images) in Oșogbo, Personal Communication, 1976.

18 Rowland Abiọdun, 1976.

19 For a more detailed discussion, see Chapter 8 of my 2014 book. 


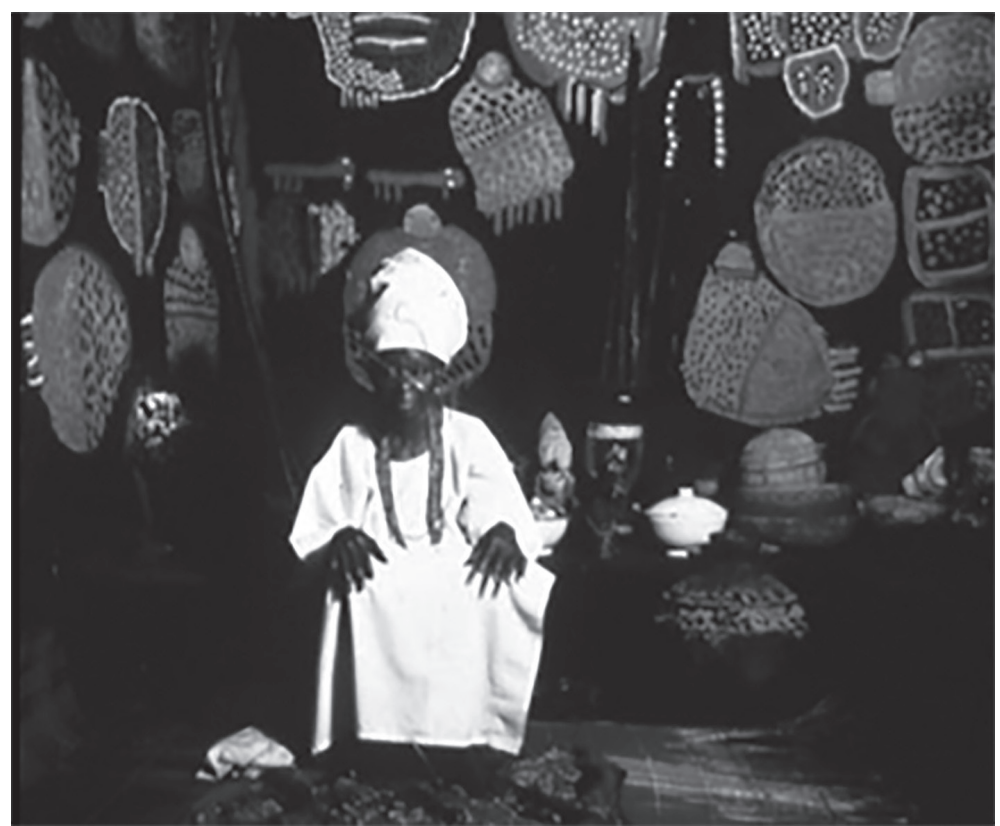

Figure 8: Priestess Omọlá jayé Oloroke at her Obalúwayé shrine, Ilé-Ifẹ. 1994. Photo by Phyllis Galembo, reproduced by permission of Phyllis Galembo.

the spontaneous acceptance or rejection of works at festivals and other public events. Yorùbá tradition enjoins obedience to established procedures and rules so that efficacy might result.

Wúrúkú l'à í-yínrinká,

Gbọọọọ-gboọrọ l'àá dọbálè

Bí ènià kò bá șe é gẹgẹ́ bí a ti i șe é

Kì írí gẹgé bí ó ti i rí. ${ }^{20}$

Kneeling-and-rolling-from-side-to-side is the woman's way of paying royal homage. ${ }^{21}$

Prostrating-face-down is the man's way of greeting his superior.

If one fails to do it the customary way,

It will not turn out as well as it always has. (My translation)

20 Adegboyega Șobande, 1967: 25.

21 Significantly, the act of rolling from side to side on the ground recalls the manner in which Orí- Àkọ kọ (the first Orí in the otherworld) paid homage to the Creator, was able to split obi-așẹ, the kola nut of așe, authority, and became the leader of all the óri șà. (See Chapter lof my 2014 book). 
Of immediate relevance to the understanding of $\dot{i}$ lutí, which can also be broadly described as a "call-response" phenomenon, is that the Yorùbá believe in the existence and intrinsic potency of primordial names of all individual living and nonliving things - a phenomenon tied to the concept of $a$ ș̣e, which has already been discussed. Consequently, the concept and possession of etí, "ears" or "good hearing" in both its physical and metaphorical sense, are essential for efficient functioning and communication in art and life.

Etí kò sí lórí

Orí dì àpólà igi. ${ }^{22}$

With the ears missing,

The head is no more than a dumb piece of wood.

This is a critical comment whose implications for Yorùbá art go beyond the physical representation of the ears. Indeed, the artist, critic, and audience all have need of $i$ lut $i$ to be able to understand, and enjoy the art object. ${ }^{23}$

Curnow neither mentioned nor discussed my original contribution to Yorubá art history through my introduction and in-depth studies of the indigenous Yoru bá aesthetic concept of Ojú-inú and İmọjú-mọra. These concepts challenge the popular but erroneous notion that ancestral or precolonial Yoru bá art were ever static, unchanging, and repetitive. What makes these concepts even more important to art historians is that they embody germs of change, initiative, and creativity that give dynamism to Yorùbá art. Ojúinú and İmojú-mọra (imagination and ability to respond to change) are not only crucial factors in the adoption of new assa techniques, and materials - in spite of the seemingly unchanging traditions of Yorùbá art - but also a means whereby the culture has managed to survive in the new environments and under the difficult conditions and enslavement in the New World. The inventiveness of the Yorùbá in the diaspora and their effective use of substitutes in art and religion most probably derive their inspiration and sanction from owe or sayings such as the following:

Bí a ò bá rí àdàn ${ }^{24}$

A à fi òòbè șẹoo.

In the absence of the big fruit bat traditionally approved for sacrifice,

22 Adegboyega Sọbande, 1967: 29.

23 Rowland Abiọdun, 2014: 272

24 Eidolon helvium. 
Another kind of bat, òobe $\dot{e}^{25}$ [house-bat which is smaller in size and lives under the eaves], may be used.

Even though quite supportive of creativity, innovation, and change, the Yorùbá caution through oju-inu and imojú-mora on the nature, reasonableness, and limit of these qualities. For example, the following proverb would be apt when judging a sculpted figure.

Kì ise pé etí kì ígùn,

Kì íse pé etí kì í ẹ̀,

Sùgbọ́n èyí tó bá șèẹsi ré ko já orí,

O' ti di ti ehoro. ${ }^{26}$

It is not that ears cannot be long.

It is not that the ears cannot be wide.

But when ears perchance shoot past the head,

Then they belong to the rabbit. (My translation)

And yet, in the same sculpture, the Yorùbá may not only permit but accept as beautiful a wider range of modes of artistic presentation, as is evident in this saying:

Bía șá kẹkeé

Aájò ẹwà là ñ șe.

Bì a b’ àbàjà,

Aájò ẹwà la niṣe.

Bí a si fẹerẹkké sílè lıọbọ̀rọ́

Aájò êwà náà la nise. ${ }^{27}$

If we have the kẹ́kẹ ${ }^{28}$ facial mark,

It is for the sake of ewa.

If we carry the àbàjà ${ }^{29}$ mark,

It is for beauty.

And if we leave the face unmarked,

It is also for the sake of ewà. (My translation).

25 Desmodus sp.

26 Adegboyega Șobande, 1967: 29

27 Adegboyega Șobande, 1967: 35.

28 Kẹ kẹ́ is a traditional facial mark among the Yorùbá. See Abraham, 1970, 300-01.

29 Àbàjà is another traditional facial mark among the Yorùbá. See Abraham, 1970, 300-01. 
Ewa' here (as fully discussed in my book) is more than "beauty" in the Western definition and concept of that term. Ewà is the expression and appreciation of iwà (the essential nature of a person or thing), as implied in the Yorủbá aphorism, "İwà l'êwa." Furthermore, making marks on the face is better understood within the context of "ạ̦a" (style, custom, tradition, a form

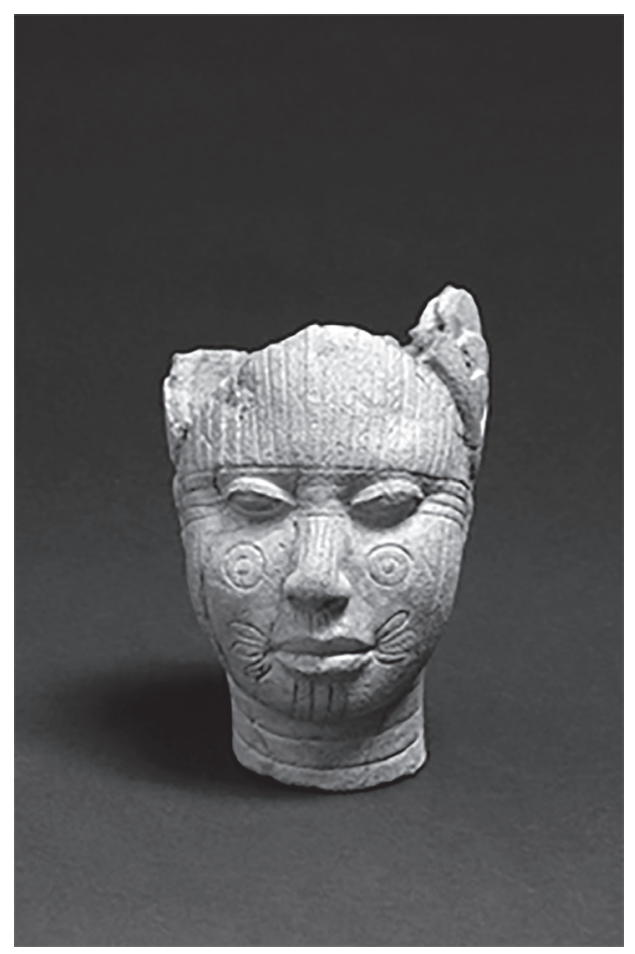

Figure 9: Head, Obalárá's land, Ifẹ. Twelfth - fifteenth century c. e., Terracotta; Height: 6 1/8ins $(15.5 \mathrm{~cm})$. Reproduced by permission of the National Commission for Museums and Monuments, Nigeria, 1999, 2.5; and courtesy of the Museum for African Art, New York, USA

of individuality which is always time framed).

Most importantly, the information conveyed in the Yoruba' saying above must be relevant to how we view and interpret the presence or the lack of facial markings in many Ifẹ heads. The following verse from Ifa' hints at the kind of oju-inu' required to understand and appreciate the creative genius of 
Ọ̀bàtálá/ Òrișanlá, the Creator divinity and the first sculptor and patron of all Yoru bá artists:
Orișañlá d'áró mẹta
O' dá kan ni dúdú
ó dá kan ní pupa
Ó dá kan ní funfun
Dúdú ni o re mí
O ògbọdọ re mí ní pupa
Dúdú ni o re mí
O ò gbọọ rẹ mí ní funfun
Íwa mi ni o kọ́ tètè rẹ
Ni' kutukutu Obarișà
Òrișànlá prepared three dyes
He made one black ${ }^{30}$
He made one red ${ }^{31}$
He made one white ${ }^{32}$
Make me black
Do not make me red
Make me black
Do not make me white
Dye me with my ì wa first
At the dawn of creation ${ }^{33}$

O'rișan'la' is the master of ojú-inu' (inner eye), for which reason he has the oríki, "Agbókunkün-sona”, the órișà who creates in total seclusion which may not be within easy reach of a "stranger" who sees only through "the nose".

During the colonial era in many parts of Nigeria, speaking in vernacular (local language) in high schools including mine was punishable by up to 12 strokes of the cane. The British colonizer did not need to be physically present for the legacy to continue. What a price to pay for "education"! Speaking, writing and thinking in English, French or Latin (which is no longer spoken but enshrined in the Classics departments of many academic institutions of former colonies) -- was actively promoted.

30 Mystery; unfathomable-ness; all colors

31 Aṣẹ-laden colors, especially red

32 Absence of color

33 Rowland Abiodun, R. 1990. "The Future of African Art Studies: An African Perspective”. In African Art Studies: The State of the Discipline. Symposium organized by the National Museum of African Art, Smithsonian Institution, Washington, DC: pages 67-68 
Today researching and theorizing African art in a colonial language and thought is the norm. The result has been a systematic undermining of an irreplaceable voice and the unique contribution of the makers and users of African art. Indeed, many scholars of Yoru bá birth are today even ashamed of being caught speaking their mother tongue, for fear of being called "illiterate", "uncivilized", "primitive", and not "forward-looking".

Other psychological repercussions of this state of affairs include hating one's language and cultural heritage. We should not be surprised, therefore, when Curnow reports that, "In 2002, an informal survey I [Curnow] conducted in Lagos, with twenty Yoruba' males under the age of thirty revealed none who could name the orișà of smallpox, none who knew of any masquerades other than egúngún, and none who had visited a diviner." This survey is not only unscientific, but it also demonstrates conclusively that the colonization process has been successful in such a large and diverse urban area. Curnow would term those "twenty Yoruba males" "outsiders" to their own culture. That said, I am inclined to believe that a similar survey conducted in the core of other Yoru bá towns like İ bàdàn, Ộwọ̀, or Ộyọ might have yielded different results.

Clearly, every language is a carrier and repository of a people's philosophy, history, psychology, religion, politics, and art. Hence, I have not only privileged but also called the Ifá literary corpus "the intellectual power house" of the Yorubá people. Too many scholars are still not inclined to spend sufficient time studying and engaging the Yoruba' language to deepen their understanding of Yoruba' art. If and when they do, they dread the moment they are confronted with the problems of cross-cultural translation and its attendant challenges. The result is that we may never have the benefit of the deep reservoir of knowledge embedded in Ifá verses, or or $i k i$ which comprises the verbal, visual and performative modes in Yoru bá thought.

So, the vexing question in African humanistic studies in general is: how much weight (if any) should scholars give to African languages in research on Africa? No doubt, most scholars find it more convenient to abandon the study and inclusion of indigenous African languages in African art historical studies but adopt instead any of the European languages mainly because it is considered 'modern', 'global' and more accessible. As I have argued in my book, the concept of Ori ki -- and not just O'we, generally translated as "proverbs"-can immeasurably deepen our understanding Yorubá Art. The following verse summarizes the centrality of Ori'ki in Yorubá art studies:

$$
\begin{aligned}
& \text { A'n'ki i' } \\
& \text { A'n'sà á } \\
& \text { Óní oun òmeni tóku' }
\end{aligned}
$$


O n'gbo' "ikúmérù

Òpàgá

Abisutabiòdòdó

Alábàokà

Arokofẹ yeje”

O ni "A'gbè lókú ni tảbi ònájà?"

We recite someone's ori ki

We intone his attributes

But an ignorant person says he does not know who has died.

He hears "Death has taken a renowned man,

A titled man,

Whose-yams-spread-like-petals

Who-possesses-a-barn-of-corn

Whose-fields-are-a-bounty-for-birds,"

The [ignorant] person still asks, "Is the dead man a farmer or a trader?"34

The fact that an art scholar has not been trained to recognize the place of ori $k i$ in the retrieval of artists' names and their histories should not lead us to conclude that Yoru ba artists are anonymous. Note how, in the book, I have used ori ki to open up new areas of investigation for the renowned Yorubá sculptor, Olọ́wẹ of İsẹ in chapter 9 of my book.

It is disconcerting that arguing for the fundamental role of languages for the study of African art still encounters opposition from the academic community -- when it is already taken for granted in the study of the arts from other parts of the world. Could it be that colonialism has taken such deep roots in the study of colonized peoples that it is no longer possible for scholars to be freed from its control in their research and theorization of African studies?

Let me invoke an incantation that could make it easier to ward off the malevolent spells such as the one that would prevent us from seeing with the "oju'-inu" - the indispensable sense that we cannot possess without fluency in Yorubá language.

Èdi òni di wa o. Așẹ.

E'di ki í múalásọ kan

E'di o ni' mú wa o. Așẹ.

May the powerful malevolent spell, Edi", never bind us. Àșe.

34 Oyekan Owomoyela, Yoruba Proverbs, University of Nebraska Press, Lincoln and London, 2005:96 
E'di, however powerful, never succeeds in causing one to remove the only clothes he/she is wearing (in the harmattan season). May Èdi never succeed in possessing our mind. Àșẹ.

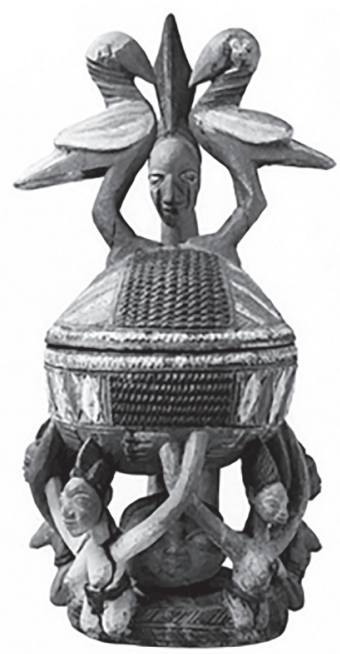

Figure 10: Agere-Ifá with figures. Artist: Olọwẹ of İsẹ. Early Twentieth century; Wood, pigment; Dimensions: $54.5 \times 35.8 \times 26.0 \mathrm{~cm}$. Walt DisneyTishman African Art Collection. Reproduced by permission of the National Museum of African Art, Smithsonian Institution, Washington, DC, USA

The only clothes Africa has left is its language and all the neo-colonial forces are poised to remove it in order to assume total control of Africa's culture, art and thought system. (It is pertinent to state that in Yoru bá culture, literal nakedness in this circumstance is regarded as a sign of mental derangement). Yet, no great civilization in the world has ever, voluntarily, given up its language for anything, no matter how precious, in order to become an "outsider" to its own culture..$^{35}$ In Ilé-Ifẹ,, an equally relevant prayer is said (in Ifẹ dialect) during the Olộjọ́ festival:

35 Okonkwo, the protagonist in Things Fall Apart by Chinua Achebe says: "Does the white man understand our custom about land? How can he when he does not even speak our tongue? But he says that our customs are bad; and our brothers who have taken up his religion also say that our customs are bad. How do you think we can fight when our own brothers have turned against us? The white man is very clever. He came quietly and peaceably with his religion. We were amused at his foolishness and allowed him to stay. Now he has won our brothers, and our clan can no longer act like one. He has put a knife on the things that held us together and we have fallen apart." 1959:176. 
Orí ló n' dá ẹni.

Èsí on dayé

Òrị̀à ló ń pa'ni í dà

Ọ́n ọn pa òrị̀à á dà

Òị̀à lọ̣ pa ní í dà

bí ísu ọn sun.

Ayé má pa tèmi dà

Kí orí mi má șe orí hẹhẹ̣

Kí o má gbà bọ̀dè

Orí is the creator of being

Before the world began

It is the Òrìsà (Supreme Being) who can change being.

No one changes Òrìșà.

It is Òrì̀à who changes one, like a yam being roasted.

Ayé (powerful worldly forces) please do not interfere with my destiny.

My Orí let me not become a laughing stock,

Do not allow evil-doers to spoil my lot.

\section{Bibliography}

Abimbola, Wande. 1968. Ijinle Ohun Enu Ifa - Apa Kinni. Glasgow: Collins. Abiodun, Rowland. 1975. "Ifa Art Objects: An Interpretation Based on Oral Traditions." In Yoruba Oral Traditions, Ed. by Wande Abimbola: pp. 421468. Ife: Department of African Languages and Literatures, University of Ife.

1976. "A Reconsideration of the Function of Ako, Second Burial Effigy in Owo." AFRICA, Journal of International African Institute 46, 1: $4-20$

1981. "Ori Divinity: Its Worship, Symbolism and Artistic Manifestation." In Proceedings of the World Conference on Orisa Tradition, pp. 484-515, Ife: Department of African Languages and Literatures, University of Ife, Ile-Ife.

.1983. "Identity and the Artistic Process in Yoruba Aesthetic

Concept of Iwa," Journal of Cultures and Ideas, 1, 1:13-30

1984. "Der Begriff Des Iwa in der Yoruba Aesthetik." Tendenzen 146: 63-68

1987. "Visual and Verbal Metaphors: Mythical Allusions in Yoruba Ritualistic Art of Ori." Word and Image 3, No. 3: 252-270

36 This verse was recited by a client of Ifa at a short religious rite for the Ooni's Ori in Ile-Ife, December 12, 1976 
1990. "The Future of African of African Art Studies: An African Perspective." African Studies: The State of the Discipline. Washington, DC: Smithsonian Institution Press.

1995. "The Dichotomy of Theory and Practice: Blocker's The Aesthetics of Primitive Art." Journal of Aesthetics Education, 29, No 3: 38-44.

1997. “Owo et le Mythe de la Benin-isation." In Arts du Nigeria, edited by Jean-Hubert Martin, Etienne Féau and Hélène Joubert, pp. 5558: Paris: Le Musè: Reunion des musès nationaux

Abraham, R. C. 1970. Dictionary of Modern Yorủbá. London: University of London Press.

Achebe, Chinua. 1962. Things Fall Apart. London: Heinemann

Crone, G. R. 1937. (ed.) The Voyages of Cadamosto and other Documents on West Africa in the Second Half of the Fifteenth Century. London: Haklyut

Frobenius, Leo. 1913 (Reprinted 1968). Voice of Africa. 2 vols. New York: Benjamin Bloom

Owomoyela, Oyekan. 2005. Yoruba Proverbs, Lincoln and London: University of Nebraska Press

Sieber, Roy. 1971. “The Aesthetics of Traditional African Art." In Art and Aesthetics In Primitive Societies, edited by Carol Jopling. New York: Dutton.

Sobande, Adegboyega. 1967. "Awon Owe Ile Wa" Olokun 7: 25-35

Thompson, Robert Farris. 1972: "The Sign of the Divine King: Yoruba Bead Embroidered Crown with Veil and Bird Decorations." In African Art and Leadership, (ed) Douglas Fraser and Herbert Cole, Madison: University of Wisconsin Press.

Willett, Frank. 1966. "On the Funeral Effigies of Owo, Benin and the Interpretation of Life-Size Bronze Heads from Ife, Nigeria." Man JRAI, N.S.1: 34-45. 